\title{
Chemosensory responses of a heterotrophic microflagellate to bacteria and several nitrogen compounds
}

\author{
M. J. Sibbald ${ }^{1}$, L. J. Albright ${ }^{1}$ \& P. R. Sibbald ${ }^{2}$ \\ ${ }^{1}$ Biological Sciences, Simon Fraser University, Burnaby, British Columbia V5A 1S6, Canada \\ ${ }^{2}$ Botany Department, University of British Columbia, Vancouver, British Columbia V6T 1N5, Canada
}

\begin{abstract}
Heterotrophic microflagellates are major grazers of bacterioplankton and play an important role in the 'microbial loop'. To date there is little information available concerning prey location by microflagellates. In environments where bacterial prey are scarce or patchily distributed, location of sufficient prey may restrict the growth and survival of microflagellates. In this report evidence is presented that a heterotrophic microflagellate, Pseudobodo tremulans, has a chemosensory prey-finding mechanism. This chemosensory ability may be an important survival mechanism of heterotrophic microflagellates living in oligotrophic waters.
\end{abstract}

Several reports (e.g. Pomeroy 1974, Azam et al. 1983) have implied that heterotrophic microflagellates ( 2 to $20 \mu \mathrm{m}$ in largest dimension) are a major link in the 'microbial loop', which cycles the nutrients and energy of dissolved organic matter to the conventional phytoplankton-herbivore grazer-fish food chain. Bacterioplankton have been identified as the major prey of small phagotrophic Protozoa in aquatic communities (Haas \& Webb 1979, Fenchel 1982b, Azam et al. 1983, Linley et al. 1983, Davies \& Sieburth 1984).

In order to obtain energy and nutrients for growth and reproduction microflagellates must find their prey. In coastal marine ecosystems where bacteria are abundant $\left(10^{6} \mathrm{ml}^{-1}\right.$; Sieburth 1984$)$ this may not be a problem; however, in some marine ecosystems, e.g. organic nutrient depleted oceanic waters, bacteria can be relatively scarce (Sieburth \& Davies 1982, Van Es \& MeyerReil 1982). Thus the problem addressed in this paper may be stated as follows: How do heterotrophic microflagellates, which prey chiefly on bacteria, locate their prey?

One method of prey location by a predator is to use a chemosensory system. The existence of such mechanisms in Protozoa has been recognised since the turn of the century (Jennings 1906). Chemosensory reactions have been demonstrated in a number of Protozoa, e.g. Tetrahymena thermophila is attracted to complex peptide mixtures and amino acid mixtures (Leick \&
Hellung-Larsen 1985), and Paramecium tetraurelia is attracted to acetate (Van Houten 1977). Much of this work has been done using 'weed species', i.e. species kept for many years in laboratory culture and consequently subject to genetic drift away from natural environmental conditions. There are a few reports in the literature of chemosensory mechanisms in Protozoa freshly isolated from the natural environment. Engelmann (1882) and Pfeffer (1888) demonstrated a response by Bodo sp., a kinetoplastid, to meat extract and other substances. Bodo sp. was also observed to aggregate around an oxygen source (Fox 1921). Since these pioneer studies with the microflagellate Bodo sp., chemosensory mechanisms have been demonstrated among the larger, structurally distinct dinoflagellates. For example both Gymnodinium fungiforme and Crypthecodinium cohnil, non-photosynthetic dinoflagellates, are attracted to certain amino acids (Spero 1985, Hauser et al. 1975). Recently, Goldman (1984) hypothesized that heterotrophic microflagellates might locate enriched microenvironments by a chemosensory mechanism. However, there is little evidence that such a mechanism is common among microflagellate species. This led us to investigate whether the marine heterotrophic microflagellate Pseudobodo tremulans has a chemosensory response.

Methods. Pseudobodo tremulans was recently isolated by P. G. Davis from the Atlantic Ocean and obtained for this work from the ATCC (American type culture collection, Maryland, USA) (\# 50061). The culture was maintained in artificial seawater (Harrison et al. 1980) with added bacteria as described by Fenchel (1982a). To test for a chemosensory mechanism, T. maze assays were carried out using the protocol of Van Houten et al. (1975) (Fig. 1). A T-maze consists of a 3way stopcock with a 2-way plug. Test solution fills one arm (T) and control solution another (C). The suspension of organisms to be tested fills the plug. When the 


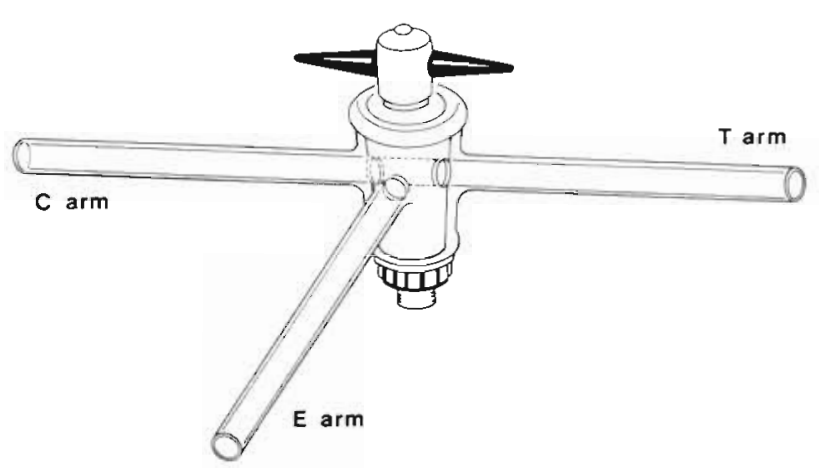

Fig. 1. T-maze apparatus

plug is turned $90^{\circ}$, the organisms interface with the test and control solutions creating a gradient of the test solution. The cells are allowed to migrate for $1 \mathrm{~h}$ in a draught-free situation at room temperature. The stopcock is then gently shut and each arm of the T-maze decanted into vials and fixed with formaldehyde ( $1.5 \%$ final concentration). Cells were stained with $4^{\prime} 6$ '-diamidino-2-phenylindole (DAPI, Sigma) and filtered onto a $2 \mu \mathrm{m}$ pore-sized, $25 \mathrm{~mm}$ diameter, Nuclepore filter, prestained with irgalan black. Cells on the filters were enumerated using epifluorescent microscopy (Filter set 487701 [BP 365/10, FT 310, and LP 395]). We concentrated our microflagellate cultures by reverse filtration through a $1 \mu \mathrm{m}$ filter to ensure we used at least 300 organisms per test. We used the equations of Van Houten et al. (1975) to calculate indices of chemosensory response and motility.

$$
\text { Index of chemotaxis }=\frac{\text { No. of cells in } T \text { arm }}{\text { No. of cells in } T \text { and } C \text { arms }}
$$

$$
\text { Index of motility }=\frac{\text { No. of cells in } T \text { and } C \text { arms }}{\text { Total no. of cells used in assay }}
$$

These indices have values between 0 and 1 . An index of chemotaxis (Ic) of 0.5 indicates that the organism is indifferent to the substance in the test arm. An Ic greater than $0.5 \mathrm{implies}$ the organism is attracted to the test substance, and an Ic less than 0.5 indicates the organism is repelled from the test substance. The index of motility was also calculated to check whether the cells moved at all. If the index was less than 0.5 we took this to indicate the cells had been damaged in preparation and the data were rejected.

Results and Discussion. Since our interest was prey location we began this study by determining whether Pseudobodo tremulans was attracted to bacteria. As test solution we used a gram-negative rod-shaped marine isolate cultured overnight in artificial seawater (ASW) and glucose (gluc), with ASW + gluc as the control solution. P. tremulans was strongly attracted to the bacteria, indicated by an Ic of 0.8 to 0.9 (Table 1). This is the first evidence that a chemosensory mechanism exists in $P$. tremulans, a marine heterotrophic microflagellate. It was not clear from this experiment whether the microflagellates were attracted to the bacteria themselves via mechanoreception or to some bacterial product via chemoreception. To address this question we filtered the bacterial culture through a $0.2 \mu \mathrm{m}$ pore size Nuclepore filter to remove bacterial cells and repeated the T-maze assay using the filtrate as the test solution. The results indicate that $P$. tremulans was attracted to a substance produced by the bacteria. In an additional experiment the bacteria were soaked, spun and resuspended in ASW 5 times and then used as a test solution. $P$. tremulans were not attracted to these bacteria (Table 1), which implies the chemical properties of the prey are important, i.e. bacterial cells without water-soluble attractants do not elicit a response from the microflagellate indicating that there is no mechanoreceptive response involved.

We also investigated the possible stimulatory effects of chemicals that are either bacterical products or microflagellate nutrient tequirements, or that had been shown to play a role in chemosensory responses of other small eukaryotes. The control solution in all cases was ASW. Test and control solutions differed by

Table 1. Pseudobodo tremulans. Chemosensory response to bacteria. Assayed as described in the text. Results are means \pm 1 standard deviation

\begin{tabular}{|llcc|}
\hline \multicolumn{1}{|c|}{ Chemical tested } & Conc. & lndex of chemotaxis & No. of replicates \\
\hline Bacteria in spent medium & Orig. conc. & $0.90 \pm 0.11$ & 8 \\
(ASW + gluc.) & $1 / 10$ diln. & $0.86 \pm 0.09$ & 8 \\
& $1 / 1000$ diln. & $0.84 \pm 0.16$ & 8 \\
Bacterized medium (filtered to & Orig. conc. & $0.92 \pm 0.10$ & 8 \\
remove bacteria) & $1 / 10$ diln. & $0.89 \pm 0.09$ & 8 \\
& $1 / 100$ diln. & $0.45 \pm 0.05$ & 8 \\
Soaked and washed bacteria, & Orig. conc. & $0.46 \pm 0.07$ & 8 \\
suspended in ASW & $1 / 10$ diln. & $0.52 \pm 0.05$ & 8 \\
& $1 / 1000$ diln. & $0.48 \pm 0.09$ & 8 \\
\hline
\end{tabular}


only one set of anions or cations where possible (so attraction or repulsion could be attributed to one ion species). For example, if potassium nitrite was added to the test solution an equivalent amount of another potassium salt was added to the control solution, thus potassium could not be held responsible for attraction or repulsion since it was present in equivalent concentration in both test and control solutions. We found that Pseudobodo tremulans was attracted to ammonium, histidine, glycine, and threonine and repelled from nitrate and nitrite (Table 2). Aspartate, proline, phenylalanine, serine, glucose, acetate, urea, and folic acid were all tested, at concentrations ranging betweeen 0.001 and $10 \mathrm{mM}$ and found to have no stimulatory effect. The results clearly establish that the heterotrophic microflagellate $P$. tremulans does exhibit a chemosensory response to several compounds (Table 2). These attractants are all chemical species that could signal the presence of prey in the marine environment.

The factor(s) released extracellularly by bacteria signals the presence of these prokaryotes and could include amino acids (Azam \& Ammerman 1984). Amino acids are also produced extracellularly by other micro-organisms, e.g. phytoplankton (Aaronson et al. 1971), released by sloppy zooplankton feeders, or released during autolysis of dead organisms (Azam \&

Table 2. Pseudobodo tremulans. Chemosensory response. Assayed as described in the text. Artificial seawater was used as the base solution, and as the control solution ( $\mathrm{C}$ arm) in all cases. All amino acids are $\mathrm{L}$ amino acids. Results are means \pm 1 standard deviation

\begin{tabular}{|c|c|c|c|c|}
\hline T-arm & & $\begin{array}{l}\text { No. of } \\
\text { replicates }\end{array}$ & $\begin{array}{c}\text { Index of } \\
\text { chemotaxis }\end{array}$ & $\begin{array}{l}\text { Index of } \\
\text { motility }\end{array}$ \\
\hline $10 \mathrm{mM}$ & $\mathrm{NH}_{4} \mathrm{Cl}$ & 5 & $0.78 \pm 0.13$ & $0.89 \pm 0.06$ \\
\hline $1 \mathrm{mM}$ & $\mathrm{NH}_{4} \mathrm{Cl}$ & 5 & $0.90 \pm 0.07$ & $0.86 \pm 0.08$ \\
\hline $0.1 \mathrm{mM}$ & $\mathrm{NH}_{4} \mathrm{Cl}$ & 5 & $0.88 \pm 0.06$ & $0.89 \pm 0.12$ \\
\hline $0.05 \mathrm{mH}$ & $\mathrm{NH}_{4} \mathrm{Cl}$ & 5 & $0.92 \pm 0.07$ & $0.90 \pm 0.14$ \\
\hline $10 \mathrm{mM}$ & Histidine & 5 & $0.80 \pm 0.19$ & $0.61 \pm 0.12$ \\
\hline $5 \mathrm{mM}$ & Histidine & 5 & $0.43 \pm 0.08$ & $0.58 \pm 0.11$ \\
\hline $0.1 \mathrm{mM}$ & Histidine & 5 & $0.35 \pm 0.09$ & $0.74 \pm 0.08$ \\
\hline $10 \mathrm{mM}$ & Glycine & 5 & $0.94 \pm 0.06$ & $0.62 \pm 0.06$ \\
\hline $5 \mathrm{mM}$ & Glycine & 5 & $0.46 \pm 0.10$ & $0.74 \pm 0.06$ \\
\hline $0.1 \mathrm{mM}$ & Glycine & 5 & $0.39 \pm 0.05$ & $0.73 \pm 0.03$ \\
\hline $10 \mathrm{mM}$ & Threonine & 5 & $0.72 \pm 0.11$ & $0.74 \pm 0.08$ \\
\hline $5 \mathrm{mM}$ & Threonine & 5 & $0.69 \pm 0.08$ & $0.76 \pm 0.04$ \\
\hline $0.1 \mathrm{mM}$ & Threonine & 5 & $0.54 \pm 0.06$ & $0.59 \pm 0.07$ \\
\hline $100 \mathrm{mM}$ & $\mathrm{NaNO}_{2}$ & 5 & $0.10 \pm 0.04$ & $0.60 \pm 0.08$ \\
\hline $10 \mathrm{mM}$ & $\mathrm{NaNO}_{2}$ & 5 & $0.42 \pm 0.07$ & $0.75 \pm 0.06$ \\
\hline $0.1 \mathrm{mM}$ & $\mathrm{NaNO}_{2}$ & 5 & $0.45 \pm 0.12$ & $0.74 \pm 0.08$ \\
\hline $100 \mathrm{mM}$ & $\mathrm{NaNO}_{3}$ & 5 & $0.08 \pm 0.04$ & $0.76 \pm 0.04$ \\
\hline $10 \mathrm{mM}$ & $\mathrm{NaNO}_{3}$ & 5 & $0.26 \pm 0.14$ & $0.77 \pm 0.11$ \\
\hline $0.1 \mathrm{mM}$ & $\mathrm{NaNO}_{3}$ & 5 & $0.35 \pm 0.08$ & $0.61 \pm 0.13$ \\
\hline
\end{tabular}

Ammerman 1984). As suggested by Azam \& Ammerman (1984) these are all situations where bacterial growth and accumulation could occur and thus represent potential sources of bacterial prey for the microflagellates.

Ammonia is an excretion product of zooplankton (Russell-Hunter 1970) including heterotrophic microflagellates (Sherr et al, 1983). In a recent paper, Goldman et al. (1985) indicated that where the prey is nitrogen limited (i.e. a high $C: N$ ratio) the heterotrophic microflagellate Paraphysomonas sp. appeared to excrete less ammonia; thus ammonia might signal healthy prey or feeding microflagellates. Marine aggregates have been reported as sites of elevated nutrient concentrations e.g. ammonia is $10^{3}$ times more concentrated in aggregates than in the surrounding water (5 $\mathrm{mM} \mathrm{NH}_{4}^{+}$; Shanks \& Trent 1979). The attraction of Pseudobodo tremulans to ammonia supports Goldman's (1984) hypothesis that a chemosensory mechanism would enable microflagellates to locate these enriched microenvironments.

There is evidence that some of the chemicals documented here as attractants for Pseudobodo tremulans are also attractants for bacteria, e.g. amino acids have been shown to be bacterial attractants (Adler 1975). It is possible that $P$. tremulans and its bacterial prey are attracted to some of the same signals. Some microflagellates are free swimmers while others have been noted to attach to particles (Fenchel 1984, Davis \& Sieburth 1984). Chemosensory behavior would help the free swimmers to detect the presence of prey and other microflagellates to locate new bacterial-enriched locations for attachment.

The concentrations of chemicals used in this study were somewhat higher than those generally found in nature. However, the concentrations of chemicals actually eliciting responses were probably lower than the concentrations used to fill the T-maze, since the cells were responding to the gradient of diffusing chemical. Moreover, the concentrations of chemicals used represent localized high concentrations such as those found in marine aggregates (Shanks \& Trent 1979).

In summary, we have demonstrated that Pseudobodo tremulans, a heterotrophic microflagellate, exhibits a chemosensory response and have defined some of the stimuli that attract this microflagellate. The positive stimulants are all chemicals that could signal the presence of prey or of feeding microflagellates. This chemosensory ability may enable $P$. tremulans to located food in the natural environment and could give the microflagellate a distinct feeding advantage when it exists in a nutrient-limited environment where prey are scarce or patchily distributed. 
Acknowledgements. We thank Drs. R. D. Fallon, S. Newell, B. F. Sherr, E. B. Sherr, and the reviewers for useful criticisms of the manuscript. This research was funded by a Natural Sciences and Engineering Research Council of Canada grant to L. J. A.

\section{LITERATURE CITED}

Aaronson, S., De Angelis, B., Frank, O., Baker, H. (1971). Secretion of vitamins and amino acids into the environment by Ochromonas danica. J. Phycol. 7: 215-218

Adler, J. (1975). Chemotaxis in bacteria. Ann. Rev. Biochem. 44: $341-366$

Azam, F., Fenchel, T., Field, J. G., Gray, J. S., Meyer-Reil, L. A., Thingstad, F. (1983). The ecological role of watercolumn microbes in the sea. Mar. Ecol. Prog. Ser. 10: $257-263$

Azam, F., Ammerman, J. (1984). Cycling of organic matter by bacterioplankton in pelagic marine ecosystems. In: Fasham, M. J. (ed.) Flows of energy and material in marine ecosystems. Plenum Press, New York, p. 345-360

Davis, P. G., Sieburth, J. McN. (1984). Estuarine and oceanic microflagellate predation of actively growing bacteria: estimation by frequency of dividing-divided cells. Mar. Ecol. Prog. Ser. 19: 237-246

Engelmann, G. (1882). Uber Sauerstoffausscheidung von Pflanzenzellen in Mikrospectrum. Bot. Ztg 40:419-426

Fenchel, T. (1982a). Ecology of heterotrophic microflagellates. II. Bioenergetics and growth. Mar. Ecol. Prog. Ser. 8: 225-231

Fenchel, T. (1982b). Ecology of heterotrophic microflagellates. IV. Quantitative occurrence and importance as bacterial consumers. Mar. Ecol. Prog. Ser. 9: 35-42

Fenchel, T. (1984). Suspended marine bacteria as a food source. In: Fasham, M. J. (ed.) Flows of energy and material in marine ecosystems. Plenum Press, New York, p. $301-312$

Fox, H. M. (1921). An investigation into the cause of the spontaneous aggregation of flagellates and into the reactions of flagellates to dissolved oxygen. J. gen. Physiol. 3: 483-512

Goldman, J. C. (1984). A conceptual role for microaggregates in pelagic waters. Bull. mar. Sci. 35: 462

Goldman, J. C., Caron, D. A., Andersen, O. K., Dennett, M. R. (1985). Nutrient cycling in a microflagellate food chain: I. Nitrogen dynamics. Mar. Ecol. Prog. Ser. 24: 231-242

Haas, L. W., Webb, K. L. (1979). Nutritional mode of several non-pigmented microflagellates from the York river estuary. J. exp. mar. Biol. Ecol. 39: 125-134
Harrison, P. J., Walters, R. E., Taylor, F. J. R. (1980). A broad spectrum artificial seawater medium for coastal and open ocean phytoplankton. J. Phycol. 16: 28-35

Hauser, D. C., Levandowsky, R. M., Hunter, S. H., Chunosoff, L., Hollwertz, J. S. (1975). Chemosensory responses by the heterotrophic marine dinoflagellate Crypthecodinium cohnii. Microb. Ecol. 1: 246

Jennings, H. S. (1906). Behaviour of lower organisms. Indiana Press, Bloomington

Leick, V., Hellung-Larsen, P. (1985). Chemosensory response in Tetrahymena: involvement of peptides and other signal substances. J. Prot. 32: 550-553

Linley, E. A. S., Newell, R. C., Lucas, M. I. (1983). Quantitative relationships between phytoplankton, bacteria and heterotrophic microflagellates in shelf waters. Mar. Ecol. Prog. Ser. 12: 77-89

Pfeffer, W. (1888). Über die chemotaktischen Bewegungen von Bakterien, Flagellaten und Volvocineen. Untersuch Bot. Inst. Tübingen 2: 582-661

Pomeroy, L. R. (1974). The oceans' food web, a changing paradigm. Bioscience 24: 499-504

Russell-Hunter, W. D. (1970). Aquatic productivity. MacMillan, New York

Shanks, A. L., Trent, J. D. (1979). Marine snow: microscale nutrient patches. Limnol. Oceanogr. 24: 850-854

Sherr, B. F., Sherr, E. B., Berman, T. (1983). Grazing, growth and ammonium excretion rates of a heterotrophic microflagellate fed with four species of bacteria. Appl. environ Microbiol. 45: 1196-1201

Sieburth, N. McN. (1984). Protozoan bactivory in pelagic marine waters. In: Hobbie, J. E., Williams, P. J. LeB. (ed.) Heterotrophic activity in the sea. Plenum Press, New York p. $405-444$

Sieburth, J. McN., Davis, P. G. (1982). The role of heterotrophic nanoplankton in the grazing and nurturing of planktonic bacteria in the Sargasso and Caribbean Seas. Annls Inst. océanogr., Paris 58 (S): 285-296

Spero, H. J. (1985). Chemosensory capabilities in the phagotrophic dinoflagellate Gymnodinium fungiforme. J. Phycol. 21: 181-184

Van Es, F. B., Meyer-Reil, L. A. (1982). Biomass and metabolic activity of heterotrophic bacteria. Adv. microb. Ecol. 6: $111-118$

Van Houten, J. (1977). A mutant of Paramecium defective in chemotaxis. Science 198: 746-748

Van Houten, J., Hansma, H., King, C. (1975). Two quantitative assays for chemotaxis in Paramecium. J. comp. Physiol. 104: 211-223 